\title{
Exploring Human Rights-Based Activism as a Social Determinant of Health: Insights from Brazil and South Africa
}

Kristi Heather Kenyon and Regiane A. Garcia*

\begin{abstract}
Social determinants of health (SDH) are usually understood as circumstances and structures that disadvantage individuals by increasing their vulnerability to disease and injury. In this model SDH act upon individuals and communities who are relatively powerless to react against the health impacts of factors such as poverty and marginalization. With the aim of expanding the concept of social determinants, we examine the role human rights-based activism can play in improving health outcomes by exploring two well-known cases: activism through Brazil's national health council, and HIV activism by South Africa's Treatment Action Campaign. Drawing on these cases we argue that, in addition to the valuable current and historical conceptions of social determinants of health as contextual factors that act upon people, social determinants can and should also be understood as processes of participation and engagement whereby individuals are able, through their own knowledge and actions, to improve health outcomes for themselves and others. Building on a phrase proposed by Heywood, we posit that human rights-based activism can be an influential agency-based social determinant of health.
\end{abstract}

\section{Introduction}

Social determinants of health (SDH) are traditionally understood as circumstances and structures disadvantaging individuals by increasing vulnerability to disease and injury. In this paradigm, social determinants act upon individuals and groups who are relatively powerless to react against the influence of factors such as poverty and social marginalization. SDH conventionally place structure at the centre, with individuals subject to the constraints of social context and economic constructs. We argue that, in addition to the valuable current and historical conceptions of SDH as contextual, usually structural, determinants that act upon people, SDH can and should also be understood as processes of participation and engagement whereby individuals are able, through their own knowledge and actions, to improve health outcomes for themselves and others. Building on Heywood's (2011) proposal: that '[w]e need to see the level of activism by civil society as a key social determinant of health', we posit that human rights-based (HRB) activism can be an influential agency-based SDH. Framing HRB activism as a SDH provides a useful lens through which to understand HRB approaches to health. Operationalizing the 'right to health' remains an ongoing challenge, particularly beyond the walls of health facilities. In presenting HRB activism as a SDH we seek to respond to this challenge of human rights practice by drawing insights from social science literature into the expanding concept of SDH, engaging with the emerging conversation on structure versus agency in this domain, and illustrating how activism can play a concrete role in understanding and improving health.

\footnotetext{
* Kristi Heather Kenyon (kristi.kenyon@up.ac.za) is a postdoctoral fellow in the Centre for Human Rights in the Faculty of Law at the University of Pretoria; her work focuses on activists on health and human rights in subSaharan Africa. Regiane Garcia (regarcia@gmail.com), a Brazilian lawyer, is a PhD candidate at the University of British Columbia Faculty of Law; her work focuses on legal frameworks and deliberative structures for collaborations between state and civil society in public health policies.
} 
In this conceptual paper we deliberately draw on successful examples with an aim of illustrating how HRB activism can function as a SDH. We explore two manifestations of this proposed SDH using case studies to depict each one: representative HRB activism in Brazil through empowered participation in the national health council, and constituency-based HRB activism on HIV in South Africa by the Treatment Action Campaign (TAC) which changes individual health-seeking behaviour. These notable cases provide well-developed examples of how HRB activism can serve as a SDH, offering insight into ways of understanding the impact of HRB approaches to health.

This article unfolds in five parts. Part 1 presents key concepts. Part 2 reviews mainstream and alternative approaches to SDH. Part 3 describes method and case selection. Part 4 puts forward two possible ways in which HRB activism can function as a SDH. Part 5 offers conclusions and recommendations.

\section{Key concepts}

\section{Activism}

Drawing on Lewis' (2002) encouragement to employ definitions that are both 'useful to think with' and 'useful to act with', we use a hybrid definition at the intersection of ideational (Hosseini 2011) and 'practice-oriented' (Dunbar-Hester 2014: xviii) approaches, focusing on the intent, actors and spaces of activism. We argue that activism is 'action on behalf of a cause' that 'goes beyond what is conventional or routine' whereby 'a range of methods [are] used by groups with relatively little institutional power attempting to influence opinion, policy or practice' (Martin 2007: 19-20). This definition positions activism as an act outside of standard practice, involving actors beyond the formal political sphere, and challenging societal distribution of power. Deviation from routine serves to disrupt the status quo (Zoller 2005: 344), and as an avenue for those without access to 'convention' to highlight and rectify 'imbalance[s] in power' (Laverack 2012: 429). As such, activism occurs largely but not exclusively outside of formal political structures also including the incorporation of unconventional actors into political processes. Activism often privileges lay over expert knowledge, highlighting experiential expertise and 'democratic participation in knowledge production' (Zoller 2005: 344). While some activists' legitimacy and motivation are tightly bound to personal experiences, others are connected through social networks, community, professional or political identity, or more amorphous ideas of solidarity.

Although health activism reflects the variety of forms discussed above (see Table 1), the study of activism within the health sphere remains limited, with 'the term health activism ... not particularly common in either popular or academic discourse' (Zoller 2005: 341).

A growing body of work in the social sciences examines the phenomenon of health social movements (HSM) defined as 'collective challenges to medical policy, public health policy and politics, belief systems, research and practice which include an array of formal and informal organizations, supporters, networks of co-operation and media' (Brown and Zavestoski 2004: 679), focusing on offering theoretical conceptualizations and categories as well as evaluating their impact (Allsop et al. 2004).

The importance of health activism and HSM is clear; important victories have been credited to activism in areas including sanitation, tobacco control, and access to anti-retrovirals for HIV (Berridge 2007; Labonté 2013), children's health, behavioural and substance-related determinants of health (Brown and Fee 2014), and concerning specific illness and disabilities (Allsop et al. 2004; Brown and Zavestoski 2004). 
Table 1: Types of Health Activism

\begin{tabular}{|c|c|c|c|c|}
\hline Actor & Form of Legitimacy & $\begin{array}{l}\text { Tradition Sphere of } \\
\text { Activity }\end{array}$ & Methods of Activism & Spaces of Activism \\
\hline $\begin{array}{l}\text { Health care } \\
\text { professionals }\end{array}$ & $\begin{array}{l}\text { Qualification, } \\
\text { expertise, } \\
\text { experience }\end{array}$ & $\begin{array}{l}\text { Health facilities, } \\
\text { unions }\end{array}$ & $\begin{array}{l}\text { Lobbying, professional } \\
\text { testimony, acting } \\
\text { against policy, } \\
\text { participation in policy- } \\
\text { making, oversight of } \\
\text { policy implementation, } \\
\text { media engagement. }\end{array}$ & $\begin{array}{l}\text { Media, public spaces, political } \\
\text { institutions, new participatory } \\
\text { spaces }\end{array}$ \\
\hline $\begin{array}{l}\text { Constituency } \\
\text { groups: } \\
\text { community } \\
\text { members, people } \\
\text { with a shared } \\
\text { health or life } \\
\text { experience }\end{array}$ & $\begin{array}{l}\text { Experience, } \\
\text { Membership }\end{array}$ & Community, NGOs & $\begin{array}{l}\text { Mobilization, media } \\
\text { engagement, public } \\
\text { protest, letter writing, } \\
\text { oversight of policy } \\
\text { implementation. }\end{array}$ & $\begin{array}{l}\text { media, public spaces beyond } \\
\text { geographic community, service } \\
\text { provision points (ie health } \\
\text { clinics), participatory fora }\end{array}$ \\
\hline $\begin{array}{l}\text { Advocates/Repre } \\
\text { sentatives: } \\
\text { associations, } \\
\text { delegates, } \\
\text { lawyers, NGOs }\end{array}$ & Representation & $\begin{array}{l}\text { Judicial system, } \\
\text { administrative } \\
\text { agencies }\end{array}$ & $\begin{array}{l}\text { Communicating } \\
\text { concerns and taking } \\
\text { action on behalf of } \\
\text { represented groups }\end{array}$ & $\begin{array}{l}\text { Participatory for a (ie health } \\
\text { councils, committee hearings, } \\
\text { etc.) }\end{array}$ \\
\hline $\begin{array}{l}\text { Health or Social } \\
\text { Justice } \\
\text { Organisation } \\
\text { (local, national, } \\
\text { international) }\end{array}$ & $\begin{array}{l}\text { Membership, } \\
\text { Solidarity }\end{array}$ & Community, NGOs & $\begin{array}{l}\text { Public protest, media, } \\
\text { online 'clicktivism,' } \\
\text { letter writing, boycotts, } \\
\text { litigation support } \\
\text { ' }\end{array}$ & $\begin{array}{l}\text { Streets, sites of national politics, } \\
\text { online, representative locations } \\
\text { (embassies, corporate } \\
\text { headquarters) }\end{array}$ \\
\hline
\end{tabular}

Activism can, however, lead to negative health outcomes where mobilization occurs in favour of dangerous forms of treatment, against positive forms of prevention (e.g. vaccines) or treatment (e.g. blood transfusions), or where activism unintentionally reduces uptake of health care services (e.g. through messages that shame populations, behaviours or conditions) or has unanticipated negative effects (e.g. promotion of breastfeeding leads to stigmatization of bottle feeding resulting in mixed feeding and higher rates of HIV transmission). Where activism advocates evidence-based treatment and access to care, in agreement with Laverack, we argue the 'way forward' is 'an acceptance of activism as a legitimate approach in the way we deliver health programming' (2013: 145).

We focus on a specific articulation of this 'way forward'-HRB activism. We view this type of activism as one that understands and expresses itself with reference to human rights including the right to health, life, non-discrimination, information, dignity, safety and security of the person, privacy and others. HRB is distinct in that, unlike other forms of activism, it is centred on a universal entitlement facilitating powerful claims backed by extensive domestic and international codification. 


\section{Participation}

Participation is integral to activism and the achievement of the right to health. This concept has been the subject of debate in relation to deliberative democracy, participatory governance, collective action, and human rights to health (Coelho 2013; London 2008). In the context of health, participatory approaches have been broadly categorized as 'target-oriented framework[s]' and 'empowerment framework[s]' (Susan Rifkin as cited in De Vos et al. 2009). We understand participation as a process whereby actors populate or claim new participatory spaces to challenge political power and expert authority and to express personal and collective identity. In line with the HRB approach to health (Potts 2008), we view participation as continuous, transparent, inclusive, and fair participatory forums or processes aiming to improve health through the meaningful participation of rights holders and accountability of duty bearers.

\section{Empowerment}

As power is central to activism and participation, we see the three concepts as strongly linked.

Empowerment has become a buzzword, rooted in multiple disciplines, and understood as a process and an outcome and as individual and collective (Bernstein et al. 1994). Rowlands traces some of this confusion to the 'disputed' 'root concept' of power dividing this into threat power ('power over') and integrative power ('power to') (Rowlands 1996: 86-7). The first is a zero sum form of power: one party compels others to behave in particular ways, reinforced by social, economic and political structures and through consequently internalized messages (ibid: 87). In contrast, integrative power is non-zero sum and can involve deriving satisfaction from skills such as leadership (ibid: 87-8). Empowerment draws on 'power to' to challenge 'power over' (Kelly as cited in Rowlands 1996: 87) — creating and acting on individual and community agency to challenge political, economic and social structures. It must 'involve undoing negative social constructions, so that people affected come to see themselves as having the capacity and right to act' and 'perceive themselves as able and entitled to occupy that decision-making space' (ibid: 87). Within the understanding that empowerment requires access to spaces of power, there are two distinct approaches: occupation and invitation (Cornwall 2002). The first entails 'expansion' of space, locating 'sites of radical possibility' that 'people make and shape for themselves' (ibid: 3 ). The second, more recent iteration, involves 'empowering' as a verb that one can do for another by 'relocating the poor within the prevailing order' (ibid: 3). Recognizing that both models serve a purpose, we place our emphasis on the former — claiming space and, in doing so, disrupting existing structures and the power they reflect and reinforce.

In the context of empowerment-based HRB activism, agency and structure hold the potential to create a positive feedback loop. HRB activism uses agency to challenge and ultimately change structure. Yet the organization and messaging of activism is affected by structural factors including political opportunity, resource mobilization, resonance, cultural context and others (McAdam et al. 1996). Actions taken by activists serve to shape subsequent practices and institutions, including methods, discourse and activist norms as well as the targets of activism (i.e. changed policies, practices). As such, agency and structure engage with each other, each shaping the other in subsequent cycles of interaction.

Despite its popularity, the operationalization of empowerment in health remains 'thorny and elusive' (Laverack and Wallerstein 2001: 179), complicated in part by the manner in which public health is structured, focusing on 'diseases and risk factors' making it difficult to 'embrac[e] the community as an empowered partner' (Syme 2004). Nonetheless, the idea has taken hold, featuring in a number of key 
documents (see UN Social Development Network (2013), Marmot (2007), and First International Conference on Health Promotion (1986)). We seek to contribute to the operationalization of the right to health, and of empowerment in health, by linking empowerment-based HRB activism to another critical concept, that of SDH.

\section{Social determinants of health}

Social determinants have broadened the discussion of factors that make people ill or well, placing the spotlight on the contexts in which people live. Beginning in the 1970s, conversations about health began to include the idea that health care is not the chief driver of people's health, a fact since acknowledged by a series of international conferences and government reports (Graham 2004).

A SDH approach has since gained widespread acceptance in fields including social medicine, public health, health policy, and human rights ${ }^{1}$ as the appropriate framework for developing and implementing public health policies and programmes. A widely-cited definition by the World Health Organization (WHO) describes SDH as the 'circumstances in which people are born, grow up, live, work and age, and the systems put in place to deal with illness' (2008). This reflects a robust body of evidence demonstrating that the health of populations is predominantly determined by social factors (Braveman et al. 2011). Ill-health is systematically associated with social disadvantage and marginalization, with the poor and the disadvantaged having poorer health, less access to services and shorter life expectancies than the rich and powerful, creating predictable patterns of 'health inequity' (Phelan et al. 2010; Braveman and Gruskin 2003; Whitehead 1992). In recent years, governments have committed to tackling health inequity, a commitment to which SDH is central and one which 'offers a better hope for sustainable and equitable outcomes' by 'redress[ing] the imbalance between curative and preventive action and individualized and population-based interventions'. ${ }^{2}$ Social determinants have, however, been criticized as 'too ambiguous to be translated into reality', with research and policies in this area critiqued for their tendency to focus on specific 'risk factors' that influence health/disease as opposed to the underlying pathways shaping and reproducing risk factors that influence health/disease (Graham 2002: 105).

\section{A way forward}

In 2005, the WHO Secretariat synthesized various SDH approaches into a single conceptual framework (WHO 2005). This framework emphasizes the central 'upstream' role of 'social position' in the unequal distribution of social determinants and health inequities. Solar and Irwin have since suggested that accurately understanding the role of social position in generating health inequities requires a thorough consideration of 'power' in creating and tackling health inequity. Like Rowlands, Solar and Irwin (2010) emphasize 'positive, creative aspects of power', arguing that:

The central role of power in the understanding of social pathways and mechanisms means that tackling the social determinants of health inequities is a political process that engages both the agency of disadvantaged communities and the responsibility of the state.

\footnotetext{
${ }^{1}$ The right to health is widely recognized in human rights documents (International Covenant on Economic, Social and Cultural Rights (ICESCR), Convention on the Rights of the Child, Convention of the Elimination of All Forms of Discrimination against Women), with 'underlying determinants' featuring in ICESCR General Comment 14, regarding Article 12.1.

${ }^{2}$ For example, the Rio Political Declaration (WHO World Conference on Social Determinants of Health, 2011).
} 
This approach links SDH to structural inequities that can be tackled through agency-based power. Unlike previous conceptions of SDH based on negative implications of the lack of power, Solar and Irwin suggest that positive, community-based power can help to tackle the roots of inequity.

We argue that HRB activism is a manifestation of power, wielded by communities and individuals, that can not only be mobilized to counter negative SDH but that can serve as a positive SDH in and of itself. Our understanding of SDH centres on Grover's comment that the right to health is a 'living part of people who enforce it themselves' (Grover and Irwin 2009). We argue that, in addition to current and historical conceptions of SDH as contextual, largely structural, determinants that act upon people, SDH can and should also be understood as empowered processes whereby individuals are able, through their own knowledge and actions, to improve personal and collective health outcomes through engagement with HRB activism. We present two illustrative case studies as an incipient attempt to connect these vital, but usually disconnected, research areas.

The SDH frame is not the only lens through which to address HRB activism on health. Dimensions of this topic have been ably examined through research in areas including social movements, deliberative democracy, health promotion, health communication, patient engagement, health and human rights, and physician advocacy. This area of study is bifurcated by disciplinary divides separating the study of activists, their organizations and movements, from human rights and health implications. As Table 2 indicates, each of these has its own disciplinary home and area of focus, reflecting the reality that although 'inter-sectoral policies to tackle the determinants of health inequalities require an interdisciplinary science of health inequalities ... research [is] located in separate disciplinary fields' (Graham 2002: 2007).

Each of the areas of research outlined in Table 2 is valuable and yet the interaction between them remains minimal. Social science research is seldom referenced in epidemiological papers and, as Chapman notes, human rights approaches to health and SDH rarely 'engag[e] in a meaningful way' (Chapman 2010: 17). Our primary contribution is to draw insights from social science research into the domain of public health, and to reframe forms of mobilization, communication and deliberation as $\mathrm{SDH}$.

What is the value of viewing activism as a SDH? As research increasingly shows, clinical care, the traditional focus of the health sciences, accounts for a small percentage of health outcomes (estimates range from 10-20 per cent), while social and economic factors (i.e. SDH) account for 21-55 per cent (Booske et al. 2010). SDH is also a concept that, although a significant departure from traditional perspectives on health, has gained considerable traction and legitimacy. The value of applying a 'social determinants of health' approach to guide the development and evaluation of policies and programmes to reduce the health gap between socio-economic groups has been widely accepted in research (Commission on Social Determinants of Health (CSDH) 2008) and incorporated into health plans (Graham 2002). Unlike social movement or deliberative democracy literature, SDH research aims to influence health policy (CSDH 2008; Marmot 2010; Preda and Voigt 2015) and is located in a field frequented and largely constituted by health care professionals. Situating our discussion as an expansion of SDH could reach and influence the way in which those working in health understand this concept. Doing so may change how they structure programmes and interact with civil society groups, providing early groundwork for a method of measuring and evaluating activism through health-seeking behaviour, policy changes or health outcomes. 
Table 2: Related Areas of Literature

\begin{tabular}{|c|c|c|c|}
\hline Area of Literature & $\begin{array}{l}\text { Primary } \\
\text { discipline(s) }\end{array}$ & Key Actor(s) & Area of Focus \\
\hline Social Movements & $\begin{array}{l}\text { Social Sciences } \\
\text { (Sociology, } \\
\text { Political } \\
\text { Science) }\end{array}$ & Social movement & $\begin{array}{l}\text { How and why movements arise, } \\
\text { message framing, when and why they } \\
\text { are effective. }\end{array}$ \\
\hline $\begin{array}{l}\text { Health Social Movements } \\
\text { (HSM) }\end{array}$ & Sociology & Health social movements & $\begin{array}{l}\text { How, why and when health oriented } \\
\text { movements arise, organise and succeed } \\
\text { or fail, what constitutes a HSM }\end{array}$ \\
\hline Deliberative Democracy & $\begin{array}{l}\text { Political } \\
\text { Science, Law }\end{array}$ & Citizen & $\begin{array}{l}\text { Ideal conditions for inclusion and } \\
\text { deliberation, and representation }\end{array}$ \\
\hline Human Rights & $\begin{array}{l}\text { Law (chiefly), } \\
\text { also social } \\
\text { sciences }\end{array}$ & Individual/State & $\begin{array}{l}\text { How and why rights are violated, how } \\
\text { to codify, enforce, promote and protect } \\
\text { rights }\end{array}$ \\
\hline $\begin{array}{l}\text { Health and Human } \\
\text { Rights/Right to Health }\end{array}$ & $\begin{array}{l}\text { Law, public } \\
\text { health }\end{array}$ & Individual/State & $\begin{array}{l}\text { How health and other human rights } \\
\text { interact, how to secure the right to } \\
\text { healthcare and healthy living conditions }\end{array}$ \\
\hline $\begin{array}{l}\text { Health Promotion / Health } \\
\text { Communication }\end{array}$ & Public health & $\begin{array}{l}\text { Public health } \\
\text { practitioners/community }\end{array}$ & $\begin{array}{l}\text { Education, engagement and support to } \\
\text { 'enabl[e] people to increase control } \\
\text { over, and to improve, their health' } \\
\text { (WHO, 2004) }\end{array}$ \\
\hline $\begin{array}{l}\text { Patient } \\
\text { Engagement/Activation }\end{array}$ & $\begin{array}{l}\text { Public health, } \\
\text { medicine, } \\
\text { nursing }\end{array}$ & Patient & $\begin{array}{l}\text { How to increase patient engagement } \\
\text { and knowledge }\end{array}$ \\
\hline Physician Advocacy & Medicine & Physician & $\begin{array}{l}\text { When, how and why physicians should } \\
\text { advocate on health issues on behalf of } \\
\text { their patients }\end{array}$ \\
\hline
\end{tabular}

\section{Method and case selection}

This article aims to illuminate the possible forms through which HRB activism could serve as a social determinant. Because we are proposing a new expanded way of understanding SDH we deliberately sought strong well-developed cases through which to depict the various forms that HRB activism could take in improving health outcomes. As such, this article does not attempt to put forward random or representative case studies; rather it deliberately presents notable successes with a view to drawing on these cases to develop a framework to be tested subsequently. In each case we focus our attention on tracing the link between HRB activism and health.

We employ two well known illustrative case studies: activism in relation to Brazil's National Health Council, and HIV activism by South Africa's Treatment Action Campaign (TAC). Brazil's health councils have achieved recognition for their unusual incorporation of activism into their structure through 
mandated participation. This participatory model has been described as one of the world's most important experiments of citizens' involvement in public policy decision-making (Gaventa 2004) with scholars suggesting that Brazil's model provides important lessons concerning inclusion and quality of deliberation (Fung and Wright 2001). South Africa's TAC has received widespread recognition for its work linking health and rights education with mobilization and litigation and has been heralded as 'probably the world's most effective AIDS group' (Rosenberg 2006; see also Friedman and Mottiar (2004), and Heywood (2009).) Our case studies draw on semi-structured interviews conducted by [XXX] with 25 members of the National Health Council in São Paulo and Brasília, Brazil in 2014, and by [XXX] with nine TAC members in the Ekurhuleni and Cape Town, South Africa, offices of TAC in 2010 and 2011 . $^{3}$ In addition to interviews, fieldwork involved observation of events and analysis of organizational documents and relevant laws.

We use these cases to identify, trace and illustrate how activism might work as a positive SDH. Our aim of focusing on forms of HRB activism as a SDH necessarily entails highlighting what can or has worked rather than what does not. We draw on different examples in the case studies to illustrate two paths activism can take as an SDH, not to ignore overlap and similarity between the cases. While we use the Brazilian case to highlight empowered participation, for example, this experience also features in the South African case. It is also important to acknowledge that although much differs between the two cases, both cases are located in countries characterized by relatively recent and transformative political change, high levels of inequality, as well as progressive constitutions and political practices. These features provide particular challenges and opportunities that shape both cases in important ways. Each path illustrated also has strengths and weaknesses. The path illustrated by the Brazilian example is dependent on specific legal structures of inclusion but stands to affect health outcomes at a variety of levels (e.g. individual, organizational, neighbourhood, national). The path depicted by the South African case presents the potential of meaningful improvements in individual health access and outcomes, but may not transform the system for others and could potentially create an imbalance in access to health services based on exposure to HRB activism.

\section{Two approaches}

\section{Empowered participation: changing context and structure}

In our first approach HRB activism serves as a SDH through an empowering process of participation. Through this process of activist participation, civil society is able to use human rights to influence policymaking, monitor implementation, and hold the state accountable for action or inaction. Here participants are recipients who are entitled to rights, but are also actors in the construction and monitoring of individual and collective rights. In this example, representative HRB activism changes structures facilitating the exercise of agency, which in turn is able to influence health policy and practice.

Although activism through participation is rarely recognized as a SDH, the role of participation in improving health outcomes is widely acknowledged with community participation at the core of many

\footnotetext{
${ }^{3}$ Interviews were carried out with 25 members of the National Health Council-15 citizen representatives, four health professionals, four government officials, and two private providers. Interviews were conducted with a representative sample of six TAC members in the Erkuhuleni district office holding a variety of leadership positions at district and community levels, and with two current and one former staff members of the national headquarters involved in national programming, education and information.
} 
international health and human rights documents. While there is increasing interest in finding effective methods for participation in health, policymakers consistently struggle with when it is suitable to involve the public, what is the most effective means to do so, and how to measure community involvement in health (see e.g. Abelson et al. (2002), Coelho (2013), Hunt and Bustreo (2013), Evans et al. (2010), McCoy et al. (2012), and Mockford et al. (2012).

\section{Brazil's National Health Council}

Brazil's health councils provide a well-developed example of how HRB activism can serve as a SDH through direct involvement in the health system that, in turn, stands to improve structures that affect health. In Brazil the right to health, itself an outcome of HRB activism (Cornwall et al. 2008), forms and regulates new spaces of participation for the creation, monitoring and accountability of state policies. Through mandated participation in institutional spaces - that is, health councils-Brazil's Constitution reconfigures the boundaries between state and citizens allowing fluid interaction (Fung and Wright 2001). In these new spaces, HRB activism reflects power-sharing by including historically excluded groups at the policy table, and incorporates accountability as these new actors can challenge political decisions. We argue that HRB activism in health councils can play an important role in translating written rights into lived rights. Although Brazil's National Health Council has not been systematically studied with regard to internal dynamics and effects on health, there is evidence from municipal-level health councils suggesting that participation in health councils results in more equitable distribution of public health services and better monitoring of service delivery. Results suggest that in locations with stronger histories of social mobilization, health councils are more active in monitoring service delivery and proposing innovative solutions to common problems (Coelho 2013). Our fieldwork in Brazil suggests that HRB activism through participation in the National Health Council has contributed to increased citizen voice and accountability in reference to policymaking and programmes, contributions that are likely to have positive health consequences.

The codification of health rights in Brazil is an illustration of the force of empowered health activism for legal change. Brazilian constitutional rights are a well known victory of the health movement that in the mid-1970s challenged social conditions, political structures of exclusion, and demanded the creation of a universal health system. Articulating health-related demands as citizenship rights, health social movements joined civil and political rights movements to fight the military authoritarian regime that ended in 1985. The Constituent Assembly was created and the Federal Constitution was ratified on 5 October 1988, codifying a myriad of rights and state obligations related to health.

The Constitution recognizes health as a social right (Article 6) for all Brazilians and as a duty of the state (Article 196). The Constitution elaborates on state obligations to guarantee health rights, including the Sistema Único de Saúde (Unified Health System, SUS), Brazil's universal health system, and participation of the community in its organization (Article 198, III). Closely associated with requirements to secure health rights are state obligations to reduce social and regional inequalities (Article 3, III), advance social justice (Preamble) and respect human dignity (Article 1, III). Federal statutes created the SUS, and mandated the development of formal spaces for citizen participation in health policymaking (Laws 8080/1990 and 8142/1990). The law orders two spaces for participation, at all levels of government (municipal, state, and national): health conferences, ${ }^{4}$ and health councils, the focus here.

\footnotetext{
${ }^{4}$ Health conferences consist of a series of formal meetings every four years to assess health and health-related needs, as well as to discuss and formulate heath proposals for the public system.
} 
Health councils are permanent deliberative bodies, whereby representatives of society, in collaboration with state representatives, formulate health strategies, approve annual plans and health budgets, and address accountability issues.

Focusing on the role of the council at the national level, we propose that participation in the council is a form of HRB activism in that new actors, ${ }^{5}$ drawn from social movements and community organizations, rely on rights to design policies that tackle context and legal obligations to monitor state actions and, in doing so, continuously challenge state decision-making power. In the national council, rights-based activism appears in several locations. First, activism appears in participants' perception that they have both the capacity and legitimacy (by law and representativeness) to contribute to undoing negative social contexts such as the lack of access to health care ${ }^{6} \mathrm{HRB}$ activism plays an important role in getting people to the council, and in shaping their involvement within it. Participants reported that they play an important part in securing health rights through roles of representation, information sharing and accountability. Members of the council understand their position as representative, with experience of activism putting a focus on 'the collective' when identifying and tackling needs. Participants described their responsibilities of representation as very broad and inclusive. One respondent explained, 'Here I represent a movement. And I came here because I was elected by many people ... a movement is not an organization, it is not formal. Everyone is part of the movement somehow, everyone can participate and give an opinion' (interview by [X], Participant 17, Brasília, Brazil, 2014). Another described her organization as existing to 'support ... the protection of the rights of the poorest populations' and 'defend ... the principles concerning the legal framework of health for all' (interview by [X], Participant 19, Sao Paulo, Brazil, 2014). Representation was seen as explicitly going beyond 'specific class interests' to ensure that 'all workers deliver quality services to society, to everyone who needs care' (interview by [X], Participant 5, Brasília, Brazil, 2014). Participants see their role in the council as 'advocates' to improve the quality of the SUS. Although doubts have been raised about the ability for participation to be truly representative, health councillors' ambition to voice broader interests while ensuring accountability to local communities aligns with a HRB approach to participation. ${ }^{7}$

Participants understand their representative role in the council as linked to accessible, transparent and continuous information sharing with their constituent communities. Communication from constituent communities to council and vice versa plays an important role in policy development as well as in providing grassroots monitoring of implementation. One respondent described the process in her organization:

$[\mathrm{M}] \mathrm{y}$ organization has widespread connections with many local communities in Brazil. This [network] facilitates needs assessment of different communities and the poorest populations, helps [us] to think of practical solutions to their problems, and participation in different levels of

\footnotetext{
${ }^{5}$ The National Health Council has 48 members, divided between citizens (50 per cent), service providers (25 per cent), and government officials and private service providers (25 per cent). Representatives serve for a two-year term and are either elected through the council board (citizen representatives) or through appointment by their current representatives (others).

${ }^{6}$ As reported by a participant regarding the Mais Médico Programa.

${ }^{7}$ See e.g. Avritzer (2007).
} 
councils helps to bring problems and propose solutions at different levels of councils. (Interview by [X], Participant 19, São Paulo, Brazil, 2014)

A high level of information sharing can bring the community into the council meeting room. One respondent reported that ' $[w]$ hen the minutes of the meeting are ready I make them available. And we will exchange information even when I am at the meeting by email, WhatsApp, and we communicate' (Interview by [X], Participant 17, Brasília, Brazil, 2014). Although information-sharing practices vary and information gaps exist, these examples indicate how such practices can directly inform participatory HRB activism and serve to improve representation.

Finally, communication plays a critical role in 'the main activity of the [national council] [which] is the monitoring over public health policies, as required by law' (interview by [X, Participant 3, São Paulo, Brazil, 2014). Communication has the potential to hold the state accountable and citizens in the council accountable to their constituent community as well. One respondent explained:

I think the debate on these levels of participation, for example, in the health council allows us to show society whether a right as constitutionally guaranteed is being fulfilled or not, at various levels, on various scales ... the debate that the council had today helps to highlight the right to health and guarantee the right. I think the council is a resort for accountability. (Interview by [X], Participant 17, Brasília, Brazil, 2014)

Providing a translation of these words into practice, one participant explained the impact the council had in challenging state service provision, stating 'we had public inquiries initiated on the recommendation of the council, for instance, on the Sanguessugas das ambulâncias [fraudulent purchase of ambulances], so we have influenced, we could influence more ... but the national council has made important contributions to the construction of the programme' (Interview by [X], Participant 8, Brasília, Brazil, 2014).

Brazil's National Health Council suggests that representative HRB activism in a formal space of participation can be an influential agency-based SDH for lay citizens either applying their expertise or through capacity-building opportunities to feel empowered and capable to make informed policy decisions that affect population health and challenge state decision-power concerning policy implementation. Our research also suggests that activism in the national council helps citizens to see themselves as representatives and advocates of specific rights of their constituent communities and of the collective dimension of the right to health. Participants reported continuously navigating a spectrum of purpose, from mitigating social stratification by bringing a plurality of voices, to accountability of their own and state actions. Our research aligns with calls for close attention to the link between records of individual activism and more active performance within formal arenas of civic engagement (Coelho 2013: 4). Virtually all participants reported a long history of civic engagement, activism and political mobilization previous to joining the national council, and became interested in issues of accountability through activism. One respondent noted, 'I become interested and involved in monitoring health programmes when I was in university. I was involved in the social health movement' (Interview by [X], Participant 2, Brasília, Brazil, 2014). Another commented 'com[ing] from an activist path, [a] leadership path, [from the] student movement, [from the] social movement. I think that helps us to see the social dimensions of public policies' (Interview by [X], Participant 15, Brasília, Brazil, 2014). Through activism in this new space of participation, citizens seem to be shapers, makers and challengers of health-related policies in ways that stand to improve health contexts, structures and outcomes. 


\section{Human rights-based activism and individual health-seeking behaviour}

In our second approach, HRB activism acts as an empowering process of engagement whereby individuals are able, through their own knowledge and actions, to improve personal health outcomes. We explore how interaction with HRB activism at an individual level alters personal behaviour with health care providers and, in doing so, improves individual health. This differs from the representative approach outlined earlier in that individuals are actors on their own behalf, claiming their health rights directly, rather than as representatives or recipients of collective action. Here individuals behave differently due to their interaction with HRB activism, seeing themselves as entitled to health care and capable of claiming it themselves.

While this approach is an important departure from conventional SDH, it reaffirms key tenets of critical SDH such as the social situation of health also indicating the importance of health literacy and patient engagement. Patients with higher levels of engagement or 'activation' are more likely to practise preventive behaviours including vaccinations and check-ups and are more likely to ask questions, know relevant treatment guidelines, seek health information and share concerns with doctors unprompted (Hibbard and Greene 2013). Consequently, 'the emerging evidence is that patients who are actively involved in their health and health care achieve better outcomes ... than those who aren't' (Dentzer 2013: 202). We propose that involvement with HRB activism can lead to these changes, functioning as a SDH by shifting power dynamics and altering the manner in which care seekers interact with health care providers and, in doing so, increasing the frequency and quality of care.

\section{South Africa's Treatment Action Campaign (TAC)}

TAC's history and activities are tightly tied to South Africa's history, with clear links to the country's most notable instance of HRB activism - the anti-apartheid struggle. The HIV activist group was established with clear symbolic and practical links to this history, founded by anti-apartheid and gay rights activist Zackie Achmat on Human Rights Day 1998, on the steps of Cape Town's St George's Cathedral - a significant location in anti-apartheid activism. While drawing on techniques and networks from the country's anti-apartheid activism, the organization takes its contemporary mandate and inspiration directly from the country's progressive post-apartheid constitution that secures the right to health care, food, water, and social assistance (Section 27, Constitution of South Africa) Explicitly human rights-based, TAC references human rights in its constitution, and, in interviews, respondents frequently identified themselves as 'human rights activists'. Identifying as a social movement, TAC has a decentralized and community-based structure, with 267 branches and 16,000 members throughout South Africa buttressing its Cape Town headquarters and five district offices.

TAC has achieved notable legal victories resulting in increased availability and affordability of HIV medication, and increased funding for health care (Heywood 2009). Widely known for litigation and protests, alongside these higher profile initiatives TAC is heavily engaged in outreach education, informing its membership and communities about the names of medications as well as legal provisions securing access to health care. Although successful by most measures, TAC has been criticized for being both pro and anti African National Congress (ANC) (Friedman and Mottiar 2004), 'narrow[ly]' focussed on ARVs (Heywood 2003), dependent on litigation (Oshry 2007), and paying insufficient attention to women's rights in relation to the prevention of mother-to-child transmission (Dubula 2010).

Involvement with TAC is a process of becoming an active participant in, rather than recipient of, health care. In many instances TAC personnel initially made contact with the organization to locate information 
and support following an HIV diagnosis. Involvement in TAC is itself a complex experience of engagement involving social support, increased knowledge about medication, the Constitution and the medical system, participation in rallies and protests and, often, eventual involvement as a community leader and educator. We argue that engagement with this process of HRB activism can change the way individuals interact with health care facilities, resulting in improved access to and quality of health care, and improved health.

TAC outreach materials typically present two types of information that challenge the disadvantaged social position of TAC's predominantly poor membership: treatment literacy and human rights education. These two types of privileged, powerful information permit TAC membership to articulate their concerns in the consequential language of doctors and lawyers. Treatment literacy materials focus on teaching members about their conditions and medication. One series of posters, for example, describes the function of drugs such as cotrimoxazole, acyclovir and fluconazole in local languages.

Knowledge of medical terminology is a powerful tool in accessing health care. Respondents described how information about their condition, obtained through engagement with HRB activism, could significantly alter the care they received. One respondent stated:

If you are not informed, I'm telling you, you will die. Every day [you will be] waking up and going to the clinic. ... [Y] ou'll wake up in the morning at 4:00, following those shoes. At 4:00 late [in the afternoon], when you're about to be attended to, you find out that there is no treatment for you.

But if you get there knowing your story, definitely show something has to be done for you. Then make sure that they cannot leave you without getting anything ... It's because you don't know that [you] get Panado $^{8}$ [it is] to say 'just go there's nothing I can do'. But if [I] know that I have peripheral neuropathy and it is not going to be healed by Panado-I need amitriptyline. Then it will be given to you. (Interview by [X], Participant 7, TAC, 2010, Erkuhuleni, South Africa)

As this quotation illustrates, a grasp of medical terminology changes the balance of power between health care providers and care recipients. This shift erodes some of the social disadvantage of TAC's population, serving as a SDH that TAC members report is correlated with improved access to care.

Materials and education campaigns also focus on human rights, encouraging those living with HIV to be familiar with the Constitution and other legal guarantees. Human rights are explicitly referenced in key organizational documents including TAC's strategic approach-TAC's website is emblazoned with the banner 'Campaigning for the rights of people with HIV/AIDS!' Posters contain references to human rights with statements such as 'claim back your right to life' or 'inform yourself to stay healthy and stand up for your rights'.

Exposure to HRB activism can change people's perceptions about the health care system and their right to access it. As Pantazidou has noted, the construction of a 'rights identity' and 'rights consciouness' (i.e. 'right to have rights') is a necessary precursor to rights claiming (2013: 268). Several respondents reported how interaction with HRB activism caused recipients to shift from an attitude of gratefully accepting whatever was offered, to a sense of rightful entitlement. One respondent described her efforts to inculcate this sense of entitlement:

\footnotetext{
${ }^{8}$ Panado is the local brand name for paracetamol/acetaminophen.
} 
I make sure that [community members] ... understand that they've got the right to access these things. ... They paid for it indirectly in the form of taxes. So they have to claim it rightfully so. They don't have to doubt. I kind of give them their rights: that they've got the right to be there. (Interview by [X], Participant 6, TAC, 2010, Ekurhuleni, South Africa)

This change from passive acceptance to entitled claims indicates a new understanding of one's position as part of the nation state and the goods it provides, as a citizen with rights.

HRB language also plays an important role in balancing power dynamics between care providers and recipients. As a consequence of this shifted balance in power, respondents noted that HRB activism enabled patients to actively interact with care providers. A respondent described what this change could look like, stating:

When you're sick, you're just happy if you see a doctor give you this medication. You've got a right to ask the doctor what is this that you are giving me? What is going to happen to my body? What changes I'm going to be experiencing? Sometimes old people they can't even read these little papers that are coming inside their medication. Maybe the doctor can explain a little bit to you to say when you drink this, you drink this because of this. We're trying maybe to reduce one, two, three, four in your health. So those are your rights as a patient or as a person. You need to know your rights. (Interview by [X], Participant 1, TAC, 2010, Ekurhuleni, South Africa)

If treatment literacy information allows individuals to speak with terminological authority, HRB activism provides them with the strength and entitlement to engage in these conversations. Together these two forms of education provide populations who are frequently disadvantaged with powerful knowledge that stands to transform the nature of health care interactions in ways that improve the quality of information, communication and care.

These individual changes in behaviour also have the implicit or explicit support of TAC's monitoring mechanisms, which act alongside individual empowerment to constitute this powerful SDH. By ensuring that care is provided as legislated and that discrimination is not practised, TAC's HRB activism serves as a guarantor of the provision of care. Drawing on their linkages to communities, TAC members can serve as the 'eyes and ears' on the ground assessing the day to day practice of health care through interaction with clinics and those who frequent them.

While monitoring usually takes place locally, enforcement occurs at various levels including participation in patient groups, or mobilization at specific health delivery sites. Where such measures fail it can involve higher-level enforcement through larger-scale protests, dialogue and formal complaints with government, and court actions.

TAC provides a clear structure of recourse if health-related expectations are not met. Individual grievances are only addressed by mass action as a last resort, with a preference for individual-level conversations. One respondent explained:

I once fought with a doctor at a ... clinic. The doctor was insulting the patients, not examining them. He would tell them: I cannot examine you because you have HIV. I don't want HIV. As a TAC member it was very wrong. I confronted the doctor. At first it didn't work. I told the project manager; she confronted the doctor. It didn't do it. The last time I confronted the doctor I was very angry and she pushed me out of the office when I told them that this is enough. I've talked to the project manager; it is not working. The next step that we are coming is that we are picketing 
now because what they are doing is one hundred per cent wrong. You shouldn't have been a doctor if you're going to treat people in this fashion. You are earning this money that you are earning because of us as people who are living with HIV. So if you don't want to examine us then you are in the wrong place. We fought with the doctor. She pushed me out of this office. She said words and stuff but we picket after that because the doctor was still there and she was still not treating patients in the right way. So we picketed and the doctor was out of the clinic. (Interview by [X], Participant 7, TAC, 2010, Ekurhuleni, South Africa)

TAC members recounted repeated stories of individual rights-claiming in health care facilities, backed by the threat of mass action.

TAC's work illustrates one way that HRB activism can function as a SDH, improving quality and access to health care through empowered education and engagement backed by collective action. Further research is needed to assess the scope of this behaviour and measure the impact on health outcomes. It is also important to investigate whether individual improvements result in a 'spillover' effect that promotes broader changes in health care delivery.

\section{Conclusions and recommendations}

This is an exploratory investigation of the expansion of SDH focuses on agency-oriented processes of participation and engagement as experienced through HRB activism. We argue that SDH can be usefully and meaningfully augmented by the addition of HRB activism and other agency-based positive determinants that enable individuals to act and own SDH. Brazil's National Health Council and TAC's work on HIV in South Africa are useful examples of how HRB activism can function as a SDH. By tracing the pathways between HRB activism and changes in health context, structure and outcomes in these cases we hope to spark new ideas of how the impacts of HRB approaches on health might be understood.

These two cases demonstrate how people enforce the right to health by creating and enacting positive determinants. Both frameworks hinge on the potential of changing power dynamics. Highlighting the importance of empowerment, Yamin (2008) and Solar and Irwin (2010) emphasize the importance for disadvantaged groups to take control over processes that affect their health. If empowerment is acknowledged to be central to the realization and operationalization of the right to health, then it is logical to locate empowerment within health's social determinants (De Vos et al. 2009). Participation and engagement with HRB activism each involve an appropriation of power by groups who have traditionally been deprived of it. Through participation, representation and communication, Brazil's National Health Council incorporates activism by and on behalf of marginalized populations into the process of healthrelated policymaking and monitoring. Through treatment literacy and human rights education, TAC adopts and enacts the power of language and collective action. By invoking the language of human rights these initiatives speak from a position of power and entitlement, claiming services and a seat at the table. These actions alter how individuals receive health care and modify the structures of health care delivery and monitoring, both actions that stand to improve health outcomes.

This conceptual paper would be usefully supplemented by systematic empirical data to establish the extent to which the paths we trace affect health outcomes. In the Brazilian case it would be instructive to 
expand the study by Coelho et al. ${ }^{9}$ to investigate whether, and how, outputs and outcomes from the National Health Council have been incorporated into the country's national health plan, and ultimately, whether and how they have improved population health among the different regions of Brazil. In South Africa it would be helpful to conduct a large $\mathrm{N}$ study examining the impact of HRB activism on access to care, quality of care, and adherence to anti-retroviral treatment .

By transgressing disciplinary boundaries, and drawing insights from research and action in the areas of health activism, human rights, and social movements we aim to shed light on how to operationalize the right to health. In proposing an expansion of SDH, we acknowledge the value and ongoing impact of structural determinants while highlighting the need for increased emphasis on the role of agency, seeing the two dimensions as mutually reinforcing. We view HRB activism as a useful and overlooked link between HRB approaches to health and SDH.

Although exploratory, this article suggests important practical implications. Framing HRB activism explicitly as a SDH means understanding it as health intervention, and viewing activists as health actors. Doing so blurs the boundaries of service provision, and questions who 'practitioners' are. This article suggests that SDH research and baseline studies should systematically include HRB activism and activists. Furthermore, groups conducting HRB activism should be incorporated into strategic planning on health in order to increase and facilitate coordination and communication between health actors.

The conceptual expansion explored in this article also stands to reconfigure the donor landscape and the categorization of initiatives as well as provide activists with a new rhetorical arsenal through which to understand, value and measure their projects in a donor setting increasingly focused on evidence and measurement. Particularly in light of the current focus on evidence-based practices, groups conducting HRB activism (and their beneficiaries) may benefit from systematically studying and tracking the health impacts of their initiatives on the constituencies with whom they work. Finally, placing individuals at the centre of SDH as actors who can improve their own health in itself is an act of increasing participation and agency, both in discourse and in reality. It may increase the breadth of who can participate in research on SDH, by increasing grassroots participation, as well as widening the scope of relevant forms of data in the study of health. This article suggests that civil society groups and activists are an often unrecognized source of health expertise, drawing on informal reporting mechanisms and deep knowledge of communities and how individuals function within them; these 'experts' stand to contribute unique, relevant and useful perspectives and techniques to challenging health problems.

\section{Funding}

This work was supported by postdoctoral funding from the Social Sciences and Humanities Research Council of Canada and the Centre for Human Rights at the University of Pretoria (to Kristi Heather Kenyon), and the Liu Institute for Global Issues at the University of British Columbia (to Regiane A. Garcia and Kristi Heather Kenyon).

\footnotetext{
${ }^{9}$ The study by Coelho et al. focuses on the São Paulo Municipal Health Council and examines how the Council affects population health within the city of São Paulo.
} 


\section{Acknowledgements}

We would like to thank participants in the Association for Social Sciences and Humanities Research in HIV Conference in Paris in 2013 who provided valuable feedback on an earlier version of this paper. We would also like to thank our two anonymous reviewers for their insightful and helpful suggestions.

\section{References}

Allsop, J., K. Jones, and R. Baggott. 2004. Health Consumer Groups in the UK: A New Social Movement? Sociology of Health \& Illness 26(6): 737-56.

Booske, B., J. Athens, D. Kindig, H. Park and P. Remington. 2010. Different Perspectives for Assigning Weights to Determinants of Health. County Health Rankings Working Paper. University of Wisconsin Population Health Institute. http://uwphi.pophealth.wisc.edu/publications/other/different-perspectives-for-assigning-weights-todeterminants-of-health.pdf.

Braveman, P., S. Egerter, and D. R. Williams. 2011. The Social Determinants of Health: Coming of Age. Annual Review of Public Health 32: 381-98.

Brown, P., and S. Zavestoski. 2004. Social Movements in Health: An Introduction. Sociology of Health \& Illness 26(6): 679-94.

Brown, T. M., and E. Fee. 2014. Social Movements in Health. Annual Review of Public Health 35: 385-98.

Chapman, A. R. 2010. The Social Determinants of Health, Health Equity, and Human Rights. Health and Human Rights 12(2): 17-30.

Coelho, V. S. P. 2013. What Did We Learn About Citizen Involvement in the Health Policy Process: Lessons from Brazil. Journal of Public Deliberation 9(1) (online).

Cornwall, A. 2002. Making Spaces, Changing Places: Situating Participation in Development. Working Paper 170. Institute of Development Studies.

Cornwall, A., J. Romano, and A. Shankland. 2008. Brazilian Experiences of Participation and Citizenship: A Critical Look. Discussion Paper Series 389. Brighton: Institute of Development Studies. .

Commission on Social Determinants of Health (CSDH). 2008. Closing the Gap in a Generation: Health Equity through Action on the Social Determinants of Health. Final report of the Commission on Social Determinants of Health. World Health Organization.

De Vos, P., W. De Ceukelaire, G. Malaise et al. 2009. Health Through People's Empowerment: A Rights-Based Approach to Participation. Health and Human Rights 11(1): 23-35.

Dentzer, S. 2013. Rx for the 'Blockbuster Drug' of Patient Engagement. Health Affairs 32(2): 202.

Dubula, V. 2010. Why Mother-To-Child Transmission Prevention is Important. In Fighting for Our Lives: The History of the Treatment Action Campaign 1998-2010, p. 24. Cape Town: Treatment Action Campaign.

Dunbar-Hester, C. 2014. Low Power to the People: Pirates, Protest, and Politics in FM Radio Activism. Cambridge, MA: MIT Press.

Evans, D., P. Pilkington, and M. McEachran. 2010. Rhetoric or Reality? A Systematic Review of the Impact of Participatory Approaches by UK Public Health Units on Health and Social Outcomes. Journal of Public Health 32(3): 418-26.

First International Conference on Health Promotion. 1986. Ottawa Charter for Health Promotion. http://www.phac- 
aspc.gc.ca/ph-sp/docs/charter-chartre/index-eng.php (referenced 22 June 2009).

Friedman, S., and S. Mottiar. 2004. A Moral to the Tale: The Treatment Action Campaign and the Politics of HIV/AIDS. Centre for Civil Society, University of KwaZulu-Natal.

Fung, A., and E. O. Wright. 2001. Deepening Democracy: Innovations in Empowered Participatory Governance. Politics and Society 29(1): 5-42.

Gaventa, J. 2004. Prefacio. In V. Coelho and M. Nobre (eds), Participação E Deliberação: Teoria Democrática E Experiências Institucionais No Brasil Contemporâneo: pp. xx-xx. Sao Paulo: Letras.

Graham, H. 2002. Building an Inter-Disciplinary Science of Health Inequalities: The Example of Lifecourse Research. Social Science \& Medicine 55(11): 2005-16.

2004. Social Determinants and their Unequal Distribution: Clarifying Policy Understandings. The Milbank Quarterly 82(1): 101-24.

Grover, A., and A. Irwin. 2009. The Power of Community in Advancing the Right to Health: A Conversation with Anand Grover. Health and Human Rights 11(1): 1-3.

Heywood, M. 2003. TAC's Focus on Anti-Retrovirals is not 'Narrow'. TAC Newsletter. http://www.tac.org.za/newsletter/2003/ns05_05_2003.htm\#Narrow.

2009. South Africa's Treatment Action Campaign: Combining Law and Social Mobilization to Realize the Right to Health. Journal of Human Rights Practice 1(1): 14-36.

. 2011. Activism as a Social Determinant of Health, SECTION 27. Equinet Newsletter. 1 May. http://www.equinetafrica.org/newsletter/index.php?issue=123.

Hibbard, J. H., and J. Greene. 2013. What the Evidence Shows about Patient Activation: Better Health Outcomes and Care Experiences; Fewer Data on Costs. Health Affairs 32(2): 207-14.

Hosseini, S. A. H. 2011. Activist Knowledge: Interrogating the Ideational Landscape of Social Movements. The International Journal of Interdisciplinary Social Sciences 5(5): 339-58.

Laverack, G. 2012. Health Activism. Health Promotion International 27(4): 429-34.

. 2013. Health Activism: Foundations and Strategies. SAGE Publications.

Laverack, G., and N. Wallerstein. 2001. Measuring Community Empowerment: A Fresh Look at Organizational Domains. Health Promotion International 16(2): 179-85.

London, L. 2008. What is a Human-Rights Based Approach to Health and Does it Matter? Health and Human Rights 10(1): 65-80.

Marmot, M. 2007. Achieving Health Equity: From Root Causes to Fair Outcomes. The Lancet 370 (9593): 1153-63.

2010. Fair Society Healthy Lives-The Marmot Review. Strategic Review of Health Inequalities in England Post-2010. http://www.instituteofhealthequity.org/projects/fair-society-healthy-lives-the-marmotreview.

Martin, B. 2007. Activism, Social and Political. In G. L. Anderson and K. G. Herr (eds), Encyclopedia of Activism and Social Justice: pp. XX-XX. SAGE Publications.

McAdam, D., J. D. McCarthy, and M. N. Zald. 1996. Introduction: Opportunities, Mobilizing Structures, And Framing Processes-Toward A Synthetic, Comparative Perspective On Social Movements. In D. McAdam, J. D. McCarthy, and M. N. Zald (eds), Comparative Perspectives on Social Movements: Political Opportunities, Mobilizing Structures, and Cultural Framings: pp. XX-XX. Cambridge University Press. 
McCoy, D. C., J. A. Hall, and M. Ridge. 2012. A Systematic Review of the Literature for Evidence on Health Facility Committees in Low- And Middle-Income Countries. Health Policy and Planning 27(6): 449-66.

Mockford, C., S. Staniszewska, F. Griffiths, and S. Herron-Marx. 2012. The Impact of Patient and Public Involvement on UK NHS Health Care: A Systematic Review. International Journal for Quality in Health Care 24(1): $28-38$.

Oshry, N. 2007. Is the Treatment Action Campaign Effective? A Literature Review. Centre for Social Science Research. http://www.cssr.uct.ac.za/sites/cssr.uct.ac.za/files/pubs/WP207.pdf.

Pantazidou, M. 2013. De-Constructing Marginality with Displaced People: Learning Rights from an Actor-Oriented Perspective. Journal of Human Rights Practice 5(2): 267-90.

Potts, H. 2008. Participation and the Right to the Highest Attainable Standard of Health. Project Report. Colchester, Essex: Human Rights Centre. http://repository.essex.ac.uk/9714.

Preda, A., and K. Voigt. 2015. The Social Determinants of Health: Why Should We Care? The American Journal of Bioethics 15(3): 25-36.

Rosenberg, T. 2006. For People with AIDS, a Government with Two Faces. The New York Times. 30 August.

Rowlands, J. 1996. Empowerment Examined. In D. Eade and M. B. Anderson (eds), Development and Social Diversity: pp. XX-XX. Oxford: Oxfam (UK and Ireland).

Solar, O., and A. Irwin. 2010. A Conceptual Framework for Action on the Social Determinants of Health. Social Determinants of Health Discussion Paper 2 (Policy and Practice). World Health Organization.

UN Social Development Network. 2013. Empowerment: What Does it Mean to You? Department of Economic and Social Affairs: Division for Social Policy and Development.

WHO. 2004. World Health Organization Health Topics: Health Promotion. http://www.who.int/topics/health_promotion/en.

2005. Action on Social Determinants of Health: Learning from Previous Experiences. Background information prepared for the Commission on Social Determinants of Health.

WHO World Conference on Social Determinants of Health. 2011. Rio Political Declaration on Social Determinants of Health. http://www.who.int/sdhconference/declaration/Rio_political_declaration.pdf (referenced 13 February 2015).

Yamin, A. E. 2008. Beyond Compassion: The Central Role of Accountability in Applying a Human Rights Framework to Health. Health and Human Rights 10(2): 1-20.

Zoller, H. M. 2005. Health Activism: Communication Theory and Action for Social Change. Communication Theory 15(4): 341-64. 